УДК $343.3 / .7$

DOI https://doi.org/10.32837/pyuv.v1i4(29).409

С. М. Мохончук

orcid.org/0000-0002-8643-6440

доктор юридичних наук, доцент,

професор кафедри крилінального права № 1

Національного юридичного університету ілені Ярослава Мудрого

\title{
МІСЦЕ ЗЛОЧИНІВ ПРОТИ МИРУ ТА БЕЗПЕКИ ЛЮДСТВА В СИСТЕМІ МІЖНАРОДНИХ ПРАВОПОРУШЕНЬ
}

Постановка проблеми. Розкриття питання про місце злочинів проти миру і безпеки людства у системі міжнародних правопорушень має не лише теоретичне, але і практичне значення. Саме суспільна небезпека певної категорії міжнародних правопорушень, їх об'єкт дозволяє національному законодавцю чітко визначати місце таких злочинів у системі кримінального кодексу та встановлювати відповідальність за їх вчинення згідно з вимогами міжнародних договорів, які є частиною національного законодавства.

Складність досліджуваного питання полягає в тому, що сьогодні наука, передусім міжнародно-правова, не встановлює єдиних понять, що стосуються правопорушень, які посягають на ті чи інші відносини, що охороняються, регулюються нормами міжнародного права. Достатньо згадати лише ті назви, якими позначають злочини за міжнародним правом - «конвенційні злочини», «кримінальні злочини міжнародного характеру», «злочини, що порушують міжнародний правопорядок» тощо [1, с. 131].

Дослідження місця злочинів проти миру та безпеки людства в системі міжнародних правопорушень є метою цієї статті.

Аналіз останніх досліджень. Вивченням особливостей правової регламентації відповідальності за злочини проти миру і безпеки людства займалися представники різних напрямів юридичної науки (міжнародного права, кримінального права, історії та теорії держави і права) залежно від специфіки аспектів, які становлять їхній науковий інтерес. Це - М.В. Буроменський, В.В. Василенко, Н.А. Зелінська, С.П. Кучевська, В.О. Навроцький, О.В. Наден.

Виклад основного матеріалу. Широко використовуються у західних дослідженнях такі терміни, як «злочин проти міжнародного права» («crime against international law»), «злочин згідно із міжнародним правом» («crime in accordance with international law»), «злочин за міжнародним правом» ( «crime under international law»). Цілком зрозуміло, що з урахуванням деякої схожості перерахованих термінів під ними часом розуміються різні види правопорушень, а відповідно, і різний ступінь визнання суспільно небезпечних діянь як злочинних при їх кваліфікації.

Тривалий час у радянській науці поширеною була класифікація міжнародних правопорушень на «міжнародні злочини» і «злочини міжнародного характеру». I.I. Карпець писав, що традиційно і головним чином за критерієм суспільної небезпеки у складі міжнародної злочинності як складного явища сучасного світу, що охоплює кілька рівнів і підрівнів, виділяються міжнародні злочини і злочини міжнародного характеру [2, с. 96].

Зазначимо, що необхідність розробки і прийняття універсального розмежування, а отже, і визначення міжнародного злочину і злочину міжнародного характеру і зараз визнається більшістю вітчизняних і іноземних вчених. Такий поділ передусім спрямований на полегшення вирішення завдання запобігання, припинення і покарання за здійснення таких правопорушень. На цю обставину звертається увага і в Резолюції Генеральної Асамблеї ООН «Заходи із запобігання міжнародному тероризму попередження міжнародного тероризму, який загрожує життю невинних людей чи призводить до їх загибелі або ставить під загрозу основні свободи, і вивчення корінних причин цих форм тероризму і актів насильства, що є наслідком зубожіння, безвихіддя, бід чи відчаю і які спонукають деяких людей жертвувати людським життям, в т. ч. і власним, у прагненні добитися радикальних змін» 42/159 від 07 грудня 1987 р. [3], оскільки основною проблемою, зокрема щодо злочинів міжнародного характеру, є відсутність єдиного критерію, який дозволив би виявити основні складові елементи визначення поняття міжнародного злочину.

Розмежовуючи міжнародні злочини і злочини міжнародного характеру, I.П. Бліщенко та I.B. Фисенко вказують, що об'єктом перших є міжнародні відносини, що регулюються міжнародним правом, вони стосуються життєвих інтересів людства. У свою чергу, об'єкт злочинів міжнародного характеру має загальнокримінальний характер у розумінні внутрішнього права. Злочини міжнародного характеру злочинці чинять зі своєї ініціативи з метою реалізації свого приватного інтересу. Збиток міжнародним відносинам 
завдається лише остільки, оскільки це необхідно для досягнення загального злочинного результату $[4$, c. 21$]$.

Злочинами міжнародного характеру визнаються передбачені міжнародними договорами суспільно небезпечні діяння (дії або бездіяльність), які не належать до міжнародних злочинів і посягають як на внутрішньодержавний, так і міжнародний правопорядок.

За своєю юридичною природою більшість із них можна віднести до загальнокримінальних злочинів, ускладнених «іноземним елементом», наприклад, створення міждержавних синдикатів по вирощуванню, виготовленню, перевезенню та збуту наркотиків або виготовлення фальшивих грошей не своїх країн. Такі злочинні діяння мають транснаціональний характер і ставлять за мету насамперед одержання надприбутків. Найбільш значною частиною цих злочинів є порушення норм, які в силу їх міжнародної небезпеки закріплені у договорах, конвенціях, міждержавних угодах. За цією ознакою подібні злочини кваліфікуються як конвенційні.

У злочинах міжнародного характеру чітко відстежується «міжнародність» діяння, часто вони межують із загальнокримінальними діяннями, наприклад, вивезення з країни і перепродаж викрадених творів мистецтва або інших цінностей. Ю.В. Трунцевський вказує: «Можна дійти висновку, що злочини міжнародного характеру - це діяння, так само як і міжнародні злочини, що зазіхають на міжнародний правопорядок, але в інших, менших масштабах, і фундаментальні основи, що стосуються не міжнародних відносин, а тільки будь-якої їхньої окремої сторони. Відповідальність за такі злочини настає відповідно до міжнародних угод (вони іноді мають регіональний характер) i національного законодавства» [5, с. 457].

Для позначення «злочинів міжнародного характеру» часто використовуються такі словосполучення, як «міжнародні кримінальні злочини», «кримінальні злочини міжнародного характеру», «міжнародні злочини кримінального характеру», «конвенційні злочини», «транснаціональні злочини» тощо. Однак, на мою думку, ці розбіжності мають передусім термінологічний характер і перераховані назви фактично є синонімами.

Зазначимо, що кількість ознак злочину міжнародного характеру чітко визначено міжнародно-правовою нормою, але вони можуть бути різноманітними й необов'язково відповідати всім ознакам, передбаченим кримінальним законам різних країн світу. Можна погодитися з думкою, що виділення таких ознак має суб'єктивний характер, тобто залежить від позиції та професійних якостей творців вказаних норм, а на практиці їх кількість є незначною.
У свою чергу, поняттям «міжнародний злочин» у контексті зазначеної класифікації охоплюються ті правопорушення, відповідальність за які несуть фізичні особи тільки за умови, що їхні діяння пов'язані зі злочинною діяльністю держав. Це зазвичай найважчі злочини, що зазіхають на основи міжнародного правопорядку, відносини, що становлять загальний інтерес. Саме до цієї категорії злочинів належать злочини проти миру та безпеки людства.

Проте класифікація міжнародних правопорушень на міжнародні злочини та злочини міжнародного характеру, хоч і є зручною, однак не єдиною. Так, I.I. Лукашук та А.В. Наумов поділяють міжнародні злочини на два основні види. До першого належать злочини 3 міжнародного права (точніше - із загального міжнародного права). Внаслідок того, що злочинність відповідних діянь встановлює загальне міжнародне право, кримінальна відповідальність за їх вчинення виникає незалежно від місця вчинення. Міжнародний кримінальний суд і суди держав мають право здійснювати правосуддя безпосередньо на основі норм міжнародного права. До іншого виду міжнародних злочинів належать злочини конвенційні, склад яких встановлюють міжнародні конвенції. Тому сферою їхньої дії є сфера юрисдикції лише тих держав, які беруть у них участь.

Автори розглядають міжнародний злочин як «винне порушення індивідом норми міжнародного кримінального права». Такий злочин, на їхню думку, потребує наявності міжнародного елемента, що може полягати у самому характерові протиправного діяння, об’єктові чи в результаті. Так, злочин може бути спрямований проти загальних інтересів миру і безпеки чи зазіхати на більш обмежені інтереси, наприклад, окремої іноземної держави [6, с. 71].

$\mathrm{У}$ підручнику з міжнародного права за редакцією О.В. Задорожного, В.Г. Буткевича, В.В. Мицика зазначено: «В українській науці міжнародного права міжнародно-правові порушення за характером наслідків і ступенем небезпеки поділяють на три види: найтяжчі міжнародні злочини; серйозні міжнародні правопорушення; ординарні міжнародні правопорушення. Найбільш тяжкі міжнародні злочини - це такі міжнародні правопорушення, що ставлять під загрозу знищення чинний міжнародний порядок, порушують права й інтереси всього світового співтовариства, зазвичай вчиняються 3 неправомірним застосуванням збройних сил, інших неправомірних примусових заходів, ставлять під загрозу існування держави тощо» [7, с. 114-115].

У роботі Н.А. Зелінської зазначено: «Поняттям «міжнародний злочин» охоплюються дві різні за характером криміналізації групи протиправних діянь: по-перше, діяння, що криміналізовані 
національним кримінальним правом (у разі, якщо вони підпадають під юрисдикцію не менш як двох держав); по-друге, діяння, що криміналізовані безпосередньо міжнародним правом» [8, с. 386]. На думку авторки, є родове поняття «міжнародний злочин», яке охоплює три види злочинів: екстрадиційні, транснаціональні та міжнародно-правові злочини. Вказується, що названі категорії не ізольовані одна від одної та здебільшого перетинаються, а така типологія є дуже умовною. Однак кожна з названих категорій має самостійне значення.

Категорію міжнародно-правових злочинів, чи «злочинів із міжнародного права» (crimes under international law), складають діяння, що криміналізовані міжнародним правом і потенційно підпадають під міжнародну кримінальну юрисдикцію. Протиправність міжнародних злочинів цієї категорії має міжнародно-правовий характер: щодо них існує міжнародно-правова заборона. Інші міжнародні правопорушення підпадають під категорії міжнародного екстрадиційного та транснаціонального злочину.

Отже, очевидним є те, що більшість авторів відносять злочини проти миру і безпеки людства до категорії найтяжчих злочинів за міжнародним правом або міжнародних злочинів.

У Статуті Міжнародного військового трибуналу, заснованого відповідно до Лондонської угоди «Про судове переслідування і покарання головних воєнних злочинців європейських країн осі» від 8 серпня 1945 р., було вказано, що міжнародноправові злочини безпосередньо порушують норми міжнародного права. Це положення також відображене у тексті вироку трибуналів.

Після завершення діяльності Нюрнберзького i Токійського військових трибуналів кримінальне переслідування індивідів, обвинувачуваних у злочинах проти людства, здійснювалося в рамках національних правових систем, тому конструкція міжнародно-правового злочину стала спиратися на національну юрисдикцію. Однак концепція «злочину із загального міжнародного права» залишалася незмінною. Значною мірою це пояснюється необхідністю узгодження 3 принципами «nullum crimen sine lege» $\mathrm{i}$ «ex post facto»: для обгрунтування поширення своєї юрисдикції на діяння, що не визнавалися злочинними внутрішньодержавним кримінальним правом, національні суди робили посилання на норми міжнародного права й універсальну юрисдикцію.

У постнюрнберзький період концепція міжнародного злочину була відображена і розвивалася у багатьох міжнародно-правових документах, таких як Конвенція про запобігання злочину геноциду і покарання за нього (1948) і Конвенція про припинення злочину апартеїду і покарання за нього (1973). У цей період активно розвивається концепція воєнних злочинів. Із середини мину- лого століття в рамках Організації Об'єднаних Націй відбувалася робота з кодификації злочинів проти миру, воєнних злочинів і злочинів проти людяності. Вже перший Проект Кодексу злочинів проти миру і безпеки людства (1954), представлений Комісією міжнародного права, містив формулювання «злочини з міжнародного права» (crimes under international law) [8, с. 389].

Особливу роль для розвитку поняття міжнародного злочину й удосконалення конструкцій його видів відіграли трибунали ad hoc по колишній Югославії та по Руанді, що були створені у 90-х рр. ХХ ст. У цей час формується «гаазька» модифікація поняття «міжнародний злочин», в основу якої була закладена пріоритетність міжнародної юрисдикції створених рішенням Ради Безпеки ООН кримінальних трибуналів ad hoc. У Статутах цих трибуналів міжнародні злочини були названі «серйозними порушеннями міжнародного гуманітарного права» .

«Гаазька» модифікація є більш широкою порівняно із «нюрнберзькою». Вона не «прив'язує» міжнародний злочин виключно до збройного конфлікту. Крім того, до кола суб'єктів цих злочинів віднесені не тільки представники державної влади, але й всі інші особи, що діють у рамках певної політики як державних, так і опозиційних сил. Саме «гаазька» модифікація міжнародного злочину відступає від уявлення про безпосередній зв'язок злочину індивіда і правопорушення держави, тобто персоніфікованого злочину держави.

Ще більш широку модифікацію міжнародно-правового злочину закладено в основу Статуту Міжнародного кримінального суду, що був прийнятий на Дипломатичній конференції в Римі 17 липня 1998 р. Статут передбачає відповідальність за найбільш серйозні злочини, які викликають стурбованість міжнародного співтовариства загалом, що підпадають під юрисдикцію постійного Міжнародного кримінального суду і прямо в ньому зазначені. У Статуті підкреслюється можливість кваліфікації будь-якого діяння як злочинного з погляду міжнародного права незалежно від юрисдикції Суду. Незважаючи на розходження в окремих елементах, єдиною концептуальною основою міжнародного злочину stricto sensu $€$ визнання загальнолюдської цінності фундаментальних прав людини. Статут Міжнародного кримінального суду до злочинів проти миру та безпеки людства відносить злочини геноциду, злочини проти людяності, воєнні злочини та злочини агреciï. На нашу думку, саме положення Статуту Міжнародного кримінального суду, що регламентують склади названих груп злочинів як найбільш повні, повинні бути максимально повно відтвореними у національному законодавстві України.

Зауважимо, що саме конвенційна регламентація міжнародних злочинів, а отже, і злочинів 
проти миру та безпеки людства сьогодні є основою для їх класифікації та визначення їх характерних рис, а існування окремої категорії міжнародних злочинів серед міжнародних правопорушень підтверджується міжнародною нормотворчістю та практикою. Крім того, саме міжнародно-правові акти визначають розмежувальні ознаками міжнародних злочинів зі злочинами міжнародного характеру та загальнокримінальними злочинами. На підставі аналізу міжнародних актів, вітчизняної та зарубіжної літератури до основних особливих ознак міжнародних злочинів можна віднести такі:

- об'єкт (особливий) кримінально-правової охорони. На цю ознаку як основну ознаку міжнародних злочинів звертають увагу більшість дослідників. Об'єкт злочину дозволяє розкрити його соціальну сутність, з' ясувати його суспільно небезпечні наслідки. Міжнародні злочини загрожують міжнародному миру і безпеці, посягають на основоположні, базові, найважливіші суспільні відносини для всієї міжнародної спільноти як єдиного цілого, а тому і розглядаються як особливо небезпечні злочини міжнародною спільнотою загалом. Відповідні злочини, як зазначає М.Ш. Басуоні, порушують інтереси всієї світової спільноти як єдиного цілого, тому що загрожують миру і безпеці людства і шокують свідомість людства [9, с. 69];

- специфіка об’єктивної сторони. Міжнародні злочини переважно утворюють складну i розгалужену діяльність багатьох суб'єктів - індивідів, юридичних осіб і держав - i вчиняються протягом тривалого часу, часто на території декількох країн [10, с. 48]. Для таких злочинів характерні значна i різнорідна група правопорушень, що об'єднуються в єдиному понятті. Як елементи тут фігурує широке коло самостійних загальнокримінальних складів. Такі злочини переважно вчиняються у рамках загального плану чи політики, поєднаних з участю значної кількості осіб у систематичних чи масових злочинних діяннях проти великої кількості жертв.

Серед ознак міжнародних злочинів, а отже, злочинів проти миру і безпеки людства визначається їх особлива тяжкість. Поєднання таких рис, як характер діяння (жорстокість, варварство) та масштабів його наслідків (масовість) є властивим для цих злочинів. Згубні наслідки вчинення міжнародних злочинів виходять за межі держав і зачіпають інтереси світового порядку. Шкода від цих злочинів не підлягає порівнянню зі шкодою від звичайних правопорушень, що робить правомірним застосування більш тяжких форм відповідальності;

- висока суспільна небезпека міжнародних злочинів як основний критерій для віднесення певних суспільно небезпечних діянь до міжнародних злочинів. Вирішальне значення тут має характер заподіюваної шкоди. У міжнародному праві диференціація режимів відповідальності сьогодні випливає не з джерела порушеної норми, а з тяжкості порушення, з важливості порушеного зобов'язання для життєвих інтересів міжнародної спільноти. Відмінність у способах забезпечення невідворотності покарання щодо загальнокримінальних злочинів і міжнародних злочинів визначається ступенем суспільної небезпеки того чи іншого злочинного діяння. Тим самим феномен соціальної небезпеки і ступінь залучення інтересів міжнародної спільноти встановлюють спосіб здійснення на практиці принципу невідворотності покарання [11, с. 56];

застосування міжнародного режиму відповідальності. Вид судової процедури визначається суспільною небезпекою вчиненого діяння: чим тяжчий злочин, тим більша необхідність у тому, щоб судовий розгляд мав міждержавний характер. 3 цієї причини у проекті Кодексу злочинів проти миру і безпеки людства передбачена можливість здійснення юрисдикції міжнародним кримінальним судом, поряд із національними судами, у разі вчинення злочинів проти миру і безпеки людства. Відповідна вказівка міститься й у Конвенції про геноцид [12];

- внаслідок вчинення міжнародних злочинів особливі правовідносини виникають між правопорушником і спільнотою держав загалом. Відповідні діяння розглядаються як злочинні усією міжнародною спільнотою;

- із міжнародними злочинами пов'язують принцип універсальної юрисдикції. Особи, винні у вчинені міжнародних злочинів, підлягають кримінальній відповідальності незалежно від місця вчинення таких злочинів. У припиненні міжнародного злочину зацікавлена уся міжнародна спільнота, тому будь-яка держава має право використати для цього необхідні засоби. Хоча у Статуті міжнародного кримінального суду такий принцип прямо не закріплений;

відповідальність за вчинення міжнародних злочинів покладається не тільки на фізичних осіб. Визнається і міжнародно-правова відповідальність держав, яка відсутня, наприклад, при вчиненні злочинів міжнародного характеру. Це випливає, зокрема, з ч. 4 ст. 25 Статуту МКС, ст. 4 проекту Кодексу злочинів проти миру і безпеки людства, ст. 58 Статей про відповідальність держав за міжнародно-протиправні діяння;

- міжнародні злочини і пов'язані з ними кримінально-правові наслідки не залежать від позиції з цього приводу національного законодавства [13, с. 422]. Комісія Міжнародного права визнала загальний принцип автономності міжнародного права щодо національного та принцип прямого застосування міжнародних норм у принципах I та II Принципів міжнародного права, визнаних Статутом Нюрнберзького трибуналу і вироком 
трибуналу. Загальне правило, покладене в основу принципу I, полягає в тому, що міжнародне право може, зовсім незалежно від права внутрішнього, накладати зобов'язання на фізичних осіб. Цей принцип також відображений у ст. 1 проекту Кодексу злочинів проти миру і безпеки людства, ст. 3, 32 Статей про відповідальність держав, ст. 27 Віденської Конвенції про право міжнародних договорів, відповідні положення згадуються й у низці рішень Міжнародного суду, відображені у роботі Ліги Націй з кодифікації норм про відповідальність держав.

М.Ш. Басуоні вважає, що злочини проти миру і людяності є міжнародними злочинами, які виросли до рівня jus cogens і становлять незменшувані (незміні) зобов'язання erga omnes [14, с. 63]. Обов'язки, які випливають з особливого статусу таких злочинів, вміщують обов'язок переслідувати або видати, незастосування будь-яких імунітетів, незастосування для захисту аргументу про «підпорядкування вищому наказу», універсальне застосування таких зобов' язань і у мирний період, і у воєнний, їхнє «незменшення» у разі крайньої необхідності для держав та універсальну юрисдикцію щодо винуватців таких злочинів.

Практика держав є незначною і недостатньою, щоб говорити про тверду юридичну основу для тверджень, що обов'язки, які випливають iз jus cogens злочинів, дійсно виконуються. Незважаючи на це, застосування цих норм міжнародного кримінального права є невід'ємним елементом у захисті прав людини й у збережені миру, а включення складів відповідних злочинів у національне законодавство є однією з найбільш важливих умов ефективної співпраці держав у боротьбі з міжнародними злочинами.

Отже, підводячи підсумок, можна констатувати, що, незважаючи на різноманітність понять, які стосуються міжнародних правопорушень, злочини проти миру та безпеки людства займають найвищий щабель серед злочинів, за які передбачена міжнародна кримінальна відповідальність. Вони віднесені до найтяжчих міжнародних злочинів, оскільки посягають на фундаментальні права людини, заборона порушення яких у міжнародному праві становить норму jus cogens, а зобов'язання держав щодо їх охорони є зобов'язанням erga omnes.

\section{Jimepamypa}

1. Панов В.П. Сотрудничество государств в борьбе с международными уголовными преступлениями : учебное пособие. Москва : Изд-во Моск. ун-та, 1993. C. 315 .

2. Карпец И.И. Международная преступность. Москва : Наука, 1988. С. 112.

3. Меры по предотвращению международного терроризма, который угрожает жизни невинных людей или приводит $\kappa$ их гибели или ставит под угрозу основные свободы, и изучение коренных причин этих форм терроризма и актов насилия, проистекающих из нищеты, безысходности, бед и отчаяния и побуждающих некоторых людей жертвовать человеческими жизнями, включая и свои собственные, в стремлении добиться радикальных перемен: Резолюция Генеральной Ассамблеи ОOH 42/159 от 07 декабря 1987 г. URL: http://daccess-dds-ny.un.org/doc/RESOLUTION/GEN/ NR0/518/49/IMG/NR051849.pdf?OpenElement.

4. Блищенко И.П., Фисенко И.В. Международный уголовный суд / предисл. В.П. Лобзякова. Москва : Закон и право, ЮНИТИ, 1998. С. 239.

5. Трунцевский Ю.В. О классификации транснациональных преступлений. Законолерности преступности, стратегия борьбы и закон / под ред. А.И. Долговой. Москва : БЕК, 2001. С. 452-459.

6. Лукашук И.И., Наумов А.В. Международное уголовное право : учебник. Москва : Спарк, 1999. C. 287.

7. Конспект лекцій з основ теорії міжнародного права / О.В. Задорожний, В.Г. Буткевич, В.В. Мицик. Київ : АТ «Мироновська друкарня», 2001. С. 115.

8. Зелінська Н.А. Міжнародно-правова концепція міжнародного злочину : дис. ... докт. юрид. наук : 12.00.11 / Ін-т законодавства Верхов. Ради України. Київ, 2007. С. 486.

9. Cherif B.M. International Crimes: Jus cogens and obligation Erga Omnes. Law and Contemporary problems: Accountability for International Crimes and Serious Violations of Fundamental Human Rights. 1996. Vol. 59, № 4. P. 69.

10. Кучевська С.П. Проблеми гармонізації законодавства України про кримінальну відповідальність та Статуту Міжнародного кримінального суду : дис. ... канд. наук : 12.00.08 / Львів. держ. ун-т внутрішніх справ. Львів, 2009. С. 327.

11. Фисенко И.В. Борьба с международными преступлениями в международном уголовном праве. Минск : «Тесей», 2000. С. 336.

12. Проект Кодекса преступлений против мира и безопасности человечества (с комментарием). URL: http://www.un.org/russian/law/ilc/draft_offences.pdf.

13. Зелінська Н.А. Міжнародні злочини і міжнародна злочинність : монографія. Одеса : Юридична література, 2006. С. 568.

14. Cherif B.M. International Crimes: Jus cogens and obligation Erga Omnes. Law and Contemporary problems: Accountability for International Crimes and Serious Violations of Fundamental Human Rights. 1996. Vol. 59, № 4. P. 63-74.

\section{Анотація}

Мохончук C. М. Місце злочинів проти миру і безпеки людства в системі міжнародних правопорушень. Стаття.

У статті розглянуто поняття міжнародних правопорушень, його еволюцію в науці, погляди вчених (українських і зарубіжних), і яке місце в цій системі правопорушень займають злочини проти миру та безпеки людства. У статті досліджуються такі поняття, як «міжнародний злочин», «злочин міжнародного характеру», «злочин проти міжнародного права», «злочин згідно із міжнародним правом», «злочин за міжнародним правом». Автор із посиланням на Резолюції Генеральної Асамблеї ООН стверджує, що основною проблемою щодо злочинів міжнародного характеру є відсутність єдиного критерію, який дозволив би виявити основні складові елементи визначення поняття міжнародного злочину. За своєю юридичною 
природою більшість із досліджуваних злочинів автор відносить до загальнокримінальних злочинів, ускладнених «іноземним елементом», оскільки такі діяння мають транснаціональний характер. У статті наголошується, що у постнюрнберзький період концепція міжнародного злочину була відображена і розвивалася у багатьох міжнародно-правових документах, таких як Конвенція про запобігання злочину геноциду і покарання за нього (1948) і Конвенція про припинення злочину апартеїду і покарання за нього (1973). На підставі аналізу міжнародних актів, вітчизняної та зарубіжної літератури до основних особливих ознак міжнародних злочинів автор відносить об'єкт (особливий) кримінально-правової охорони, специфіку об'єктивної сторони, високу суспільну небезпеку, застосування міжнародного режиму відповідальності. Також автор робить такі висновки: внаслідок вчинення міжнародних злочинів особливі правовідносини виникають між правопорушником і спільнотою держав загалом; is міжнародними злочинами пов'язують принцип універсальної юрисдикції; міжнародні злочини та пов'язані з ними кримінально-правові наслідки не залежать від позиції з цього приводу національного законодавства; відповідальність за вчинення міжнародних злочинів не тільки покладається на фізичних осіб, але визнається і міжнародно-правова відповідальність держав.

Ключові слова: міжнародні правопорушення, злочини проти миру та безпеки людства.

\section{Summary}

Mokhonchuk S. M. Place of crimes against the peace and security of mankind in the system of international crimes. - Article.

The article explores the concept of international crimes, its evolution in science, the views of scientists (Ukrainian and foreign), and the place of crimes against peace and security of mankind in this system. The article explores such concepts as "international crime", "crime of an international nature", "crime against international law", "crime in accordance with international law", "crime under international law". Referring to the UN General Assembly Resolutions, the author states that the main problem with crimes of an international nature is the lack of a single criterion that would reveal the main components of the definition of an international crime. By its legal nature, most of the investigated crimes are attributed to general criminal offences complicated by a "foreign element" since such acts are transnational. The article concludes that in the post-Nuremberg period, the concept of international crime was reflected and developed in many international legal instruments, such as the Convention on the Prevention and Punishment of the Crime of Genocide (1948) and the Convention on the Suppression and Punishment of the Crime of Apartheid (1973). The author analyzed international acts, domestic and foreign literature, and concluded that the main distinctive features of international crimes are the subject of (special) criminal-law protection, the specificity of the objective party, severe social danger, the use of international liability regime. According to the author, the following characteristics are also important: as a result of committing international crimes, unique legal relationships arise between the offender and the community of states as a whole; are bound by the principle of universal jurisdiction with international crimes; international crimes and their associated criminal consequences are independent of national law; responsibility for committing international crimes rests not only on individuals but also recognizes the international legal responsibility of states.

Key words: international crimes, crimes against the peace and security of mankind. 